\title{
Aspects of Mechanical Stress Grading for Structural Timber
}

\author{
Julio César Pigozzo ${ }^{1}$, Felipe Nascimento Arroyo², Raquel Schmitt Cavalheiro ${ }^{3}$, \\ André Luis Christoforo ${ }^{2, *}$, Everaldo Pletz ${ }^{4}$, Francisco Antonio Rocco Lahr ${ }^{5}$ \\ ${ }^{1}$ Department of Civil Engineering, Technology Center, State University of Maringá (UEM), Maringá, Brazil \\ ${ }^{2}$ Centre for Innovation and Technology in Composites - CIT ${ }^{\mathrm{e}} \mathrm{C}$, Department of Civil Engineering (DECiv), \\ Federal University of São Carlos, São Carlos, Brazil \\ ${ }^{3}$ Department of Materials Engineering, São Paulo University (EESC/USP), São Carlos, Brazil \\ ${ }^{4}$ University Center Dynamics of Cataratas, Foz do Iguacu, Brazil \\ ${ }^{5}$ Department of Structural Engineering, São Paulo University (EESC/USP), São Carlos, Brazil
}

\begin{abstract}
The development of standard methods and criteria for the stress grading of structural timber elements by non-destructive, fast and cheap bending tests, will allow producers, distributors and customers of such elements, have a better control of the marketed product. This paper analyzes the most suitable length of free span for stress grading of structural timbers, number of points to be assayed in each element, data precision and evaluation of cost of these tests for small business.
\end{abstract}

Keywords Stress grading, Structural size pieces, Mechanical characteristics

\section{Introduction}

Wood is a wide-spread used in several applications such as in construction [1-3] whose useful potential is growing due to the introduction of new technologies as the laminated glued wood [4-6].

As found by [7] there are many difficulties in the recognition of species available in the market, which are usually from far regions and marketed with regional names. In his studies, the author described that from a set of sixty eight samples, twenty one were positively identified, from which eighteen percent had changed names and twenty nine percent were identified with the regional name or similar ones.

Even nowadays, it still being developed timber structural projects based on strength classes, regarding the species marketed in certain region. Based on the mechanical stress grading, not yet applied by most of timber producers and distributors it will be allowed to group several species with similar mechanical characteristics, joining the pieces with better properties into the top strength class resulting in better rationality in the usage of the forestry resources as in higher use and safety of the structural timbers. The classification process does not look for choosing the defect-free pieces, but instead to admit the higher number of defects without unnecessary discard of material.

* Corresponding author:

alchristoforo@gmail.com (André Luis Christoforo)

Published online at http://journal.sapub.org/ijme

Copyright (C) 2016 Scientific \& Academic Publishing. All Rights Reserved
Classification of structural timber by non-destructive bending tests is universally accepted, however the loading, relation between free span and specimen thickness and natural variability result in spread results. For local timber samples many important conclusion have been drawn for definition of normative methods and criteria, based on bending tests with the load applied in the center of the free span. These tests were considered fast, simple and of low cost for a preliminary classification at producers, distributors and even customers of structural timber products. Such preliminary classification will give to the specimens the same treatment conditions as those given to other structural materials and the knowledge of the mean resistance of a lot will not discard the normalized characterization.

Made some non-destructive bending tests applying the load at the center of the $3.00 \mathrm{~m}$ free span in Peroba Rosa (Aspidosperma polyneuron) samples, with $6.0 \times 16.0 \mathrm{~cm}$ cross section. He idealized a worksite test with simple equipment and small changes in the loading point and performed by untrained staff. The load was a 20 or $50 \mathrm{~kg}$ block hanging on the beam. The same samples were assayed in the laboratory in the static mode and controlled loading of $10 \mathrm{MPa} / \mathrm{min}$, resulting in modulus of elasticity in static bending (E) with averages comparable within 95\% confidence level. Variation coefficients of $21.72 \%$ and $17.36 \%$ were determined for the worksite and laboratory assays respectively. Linear regression analysis revealed correlation coefficient of 0.8741 between the elasticity modulus. The average assaying time were two minutes in the worksite and ten to fifteen minutes in laboratory.

Studied the bending modulus of elasticity in samples of 
eight Brazilian species, $\mathrm{L} / \mathrm{h}$ ratio, the $\mathrm{L}$ is the free span and $\mathrm{h}$ is the height of the piece, using beams supported in both ends with centered load by the expression: $E_{a}=P L^{3 / 48 f I}$ (disregarding the effect of the cutting forces in the displacement $\mathrm{f}$ ). The author demonstrated that the apparent bending modulus of elasticity, $E_{a}$, was constant in the $21<$ $\mathrm{L} / \mathrm{h}<26$, meaning that $\mathrm{E}_{\mathrm{a}}$ has the same value as the real modulus for $\mathrm{L} / \mathrm{h}=21$. Relating $\mathrm{E}_{\mathrm{a}}$ with the two dimensions of the section of the pieces, $\mathrm{b} / \mathrm{h}$, and using Paraná Pine (Araucária angustifólia) and Peroba Rosa (Aspidosperma polyneuron), it was demonstrated that the bending modulus of elasticity (E) do not change with $\mathrm{b} / \mathrm{h}$ for a given $\mathrm{L} / \mathrm{h}$ ratio. Comparing the real bending modulus of elasticity $(\mathrm{E})$ and the parallel compression modulus of elasticity it was demonstrated that the average values agreed within a $95 \%$ confidence level. [8-9].

Studied six timber samples from Para State (Brazil), with cross section of $5.08 \times 10.16 \mathrm{~cm}(2$ " $\times 4$ ") submitting such beams to a non-destructive bending assay in a Computermatic MK P IVa mechanical classifying machine. The $2617 \mathrm{~N}$ load was applied in the center of a $91.44 \mathrm{~cm}$ (3') free span, taking the displacements at each $15.24 \mathrm{~cm}$ all along the specimen, with a linear speed of $60 \mathrm{~m} / \mathrm{min}$. The same samples were assayed in laboratory simulating the static condition used by the classifying machine, but with a displacement speed of $8.23 \mathrm{~mm} / \mathrm{s}$. The loading were applied at the points: weaker, stronger and central of each specimen as indicated by the machine. Comparing the modulus of elasticity obtained in the laboratory with those from the classifying machine a coefficient of correlation of 0.77 was found using linear regression, although a higher value was expected. The differences were attributed to the higher speed of the machine (110 times higher) and displacement of the specimens influenced the results [10].

Concluded that the speed of deformation from 6.3 to 37 $\mathrm{MPa} / \mathrm{min}$ do not significantly affect the results of the bending modulus of elasticity, thus for each $1000 \%$ of increase in the speed there is a $5 \%$ increase in the $\mathrm{E}_{\mathrm{M}}$, justifying the use of loads in the shape of controlled weight blocks, but did not used loading speeds as fast as those applied by the classifying machines [11].

Proposed a non-destructive visual and mechanical Classifying assay based on bending and using free spans of 1.50 and $3.00 \mathrm{~m}$ with central loading for the evaluation of the timber pieces received in worksites, to be used in reinforced concrete molding. The authors observed that the structural function of the pieces were temporary and their dimensions represented battens, rafters and props.

As those previous papers were developed at different times and with different focus it is not possible to draw an ultimate conclusion concerning the mechanical classification of structural timber pieces [12].

Thus the present works aim to define the most adequate free span for non-destructive bending assays for structural timber pieces considering the commercial dimensions, defining the minimum number of sampling points, analyzing the precision of the results and analyzing the cost of such assays.

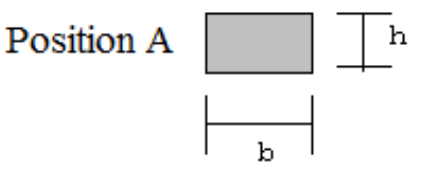

$\mathrm{L} / \mathrm{h}=50$

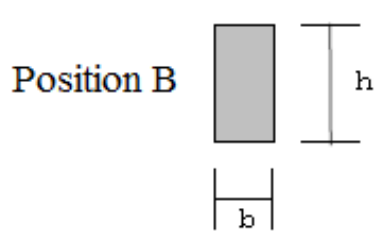

$\mathrm{L} / \mathrm{h}=25$

\section{Beam of 4.00 meters}
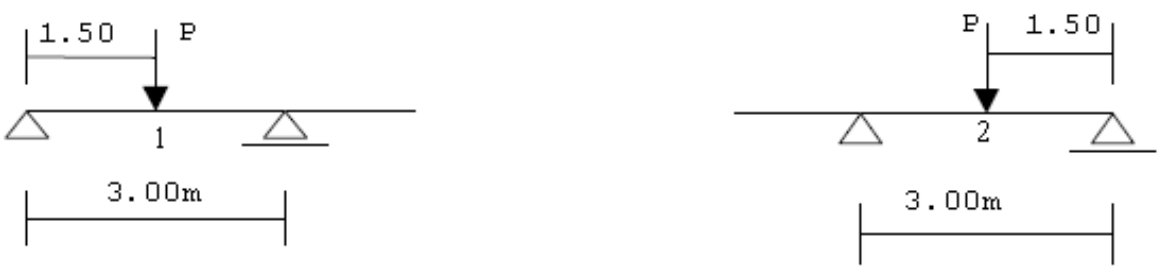

Beam of 5.00 meters
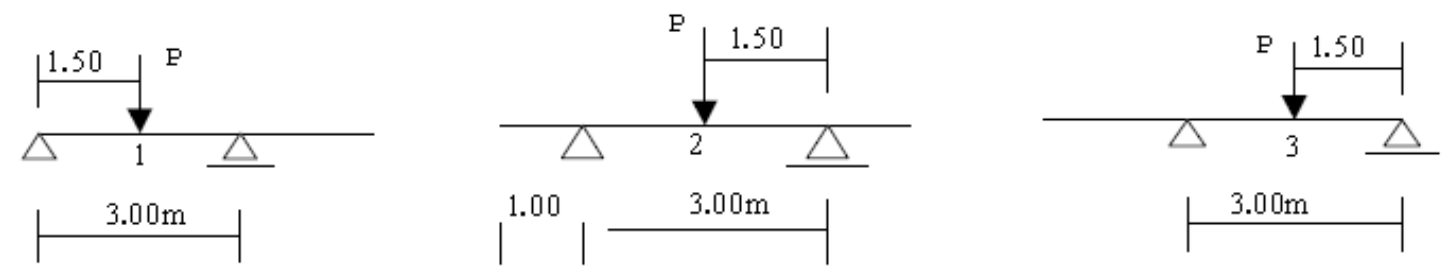

Figure 1. Representation of the strength in the beams assayed 


\section{Material and Methods}

Twelve specimens from Envira (Sterculia sp) wood, were subjected to simple bending assays with loading in the Center of the $3.00 \mathrm{~m}$ free span, all of them with nominal cross section of $6.00 \times 12.0 \mathrm{~cm}$, being six of these specimens $4.00 \mathrm{~m}$ and other six 5.00 of total length. These pieces were assayed with loadings at $\mathrm{A}$ and $\mathrm{B}$ positions, respectively perpendicular to the lower and higher inertia axis at points 1 and 2 for the $4.00 \mathrm{~m}$ and at 1, 2 and 3 for the $5.00 \mathrm{~m}$ long beams, as represented in Figure 1.

The loadings at 4.5 to $5.0 \mathrm{MPa} / \mathrm{min}$, were increasingly applied up to displacements, at the loading point, of L/200 $\mathrm{cm}$. The bending modulus of elasticity (E) was determined by the expression: $E=P / f \cdot\left(L^{3 / 48} \cdot I\right)$, being $\mathrm{P} / \mathrm{f}$ the ratio between the loading and displacement at point in which the load is being applied, obtained by the linear regression with the results of the assays, $L$ the free span and I the moment of inertia of the section with dimensions $b$ and $h$ of the point in which the loading is being applied. The moduli of elasticity were then corrected for $12 \%$ of humidity, according to the Brazilian Standard [13].

\section{Statistical Analysis}

In order to check the hypothesis $\mathrm{H}_{0}$ according to which the samples are from the same population, that means $\mu_{1}=\mu_{2}$ as well as $\sigma_{1}=\sigma_{2}$ the score $t$ is adopted, according to [14].

$$
t=\frac{\bar{X}_{1}-\bar{X}_{2}}{S \sqrt{1 / N_{1}+1 / N_{2}}} \text { in which: } S=\sqrt{\frac{N_{1} \cdot S_{1}^{2}+N_{2} \cdot S_{2}^{2}}{N_{1}+N_{2}-2}}
$$

Being $N_{1}$ and $N_{2}$ the size, $S_{1}^{2}$ and $S_{2}^{2}$ the variance
$\bar{X}_{1}$ and $\bar{X}_{2}$ the average values for the samples. Based on the bilateral test within $95 \%$ of confidence level, $\mathrm{H}_{0}$ is acceptable when $t$ falls within the $\mathrm{t}_{0.025} \mathrm{a} \mathrm{t}_{0.975}$ interval for the degree of freedom $U=N_{1}+N_{2}+2$.

\section{Results and Discussion}

Tables 2 to 6 present the individual results for the modulus of elasticity of the structural pieces as well as the average value, variance coefficient and average of the variances.

The ration between the applied load and the displacement of a beam depends on its average stiffness, however as can be seem from Table 1, from which each the dimensions may vary up to $3 \%$ of the nominal dimension, resulting in a variation of $12 \%$ in the moment of inertia regarding the nominal moment of inertia. Table 7 presents the moment of inertia calculated with the beam dimensions at the loading point, according to the data in Table 1.

\section{Cost for Classification of Structural Pieces}

The estimative of the cost for the classification of structural pieces is based on the hypothesis that two workers classifying one bean each three minutes during ten days produced fifty cubic meters of classified wood, equivalent to the month production of a small dealer. It is also considered the expenses with salaries reach $\mathrm{R} \$ 1,800.00$ (one thousand and eight hundred Brazilian reais) per month, thus an R\$ 600.00 (six hundred Brazilian reais) for a 10 days period. This cost represents c.a. one and a half cubic meter of lumber, thus $3 \%$ of the marketed amount.

Table 1. Dimensions and humidity of the beams

\begin{tabular}{|c|c|c|c|c|c|}
\hline Beam & Dimensions (cm) & Humidity (\%) & Beam & Dimensions (cm) & Humidity (\%) \\
\hline & Point $1-12.14 \times 6.14$ & & & Point $1-12.02 \times 5.82$ & \\
\hline \multirow[t]{3}{*}{4.1} & Point $2-12.15 \times 6.27$ & 25.68 & 5.1 & Point $2-12.14 \times 5.87$ & 20.42 \\
\hline & & & & Point $3-11.98 \times 5.83$ & \\
\hline & Point $1-11.98 \times 6.13$ & & & Point $1-12.00 \times 6.06$ & \\
\hline \multirow[t]{3}{*}{4.2} & Point $2-12.00 \times 6.02$ & 25.79 & 5.2 & Point $2-12.09 \times 6.04$ & 20.36 \\
\hline & & & & Point $3-11.91 \times 6.09$ & \\
\hline & Point $1-12.02 \times 6.14$ & & & Point $1-12.05 \times 6.33$ & \\
\hline \multirow[t]{3}{*}{4.3} & Point $2-11.96 \times 6.00$ & 20.25 & 5.3 & Point $2-12.04 \times 6.27$ & 20.38 \\
\hline & & & & Point $3-12.11 \times 6.19$ & \\
\hline & Point $1-12.01 \times 6.26$ & & & Point $1-12.07 \times 6.05$ & \\
\hline \multirow[t]{3}{*}{4.4} & Point $2-11.60 \times 6.22$ & 22.14 & 5.4 & Point $2-12.07 \times 6.10$ & 36.69 \\
\hline & & & & Point $3-12.09 \times 6.18$ & \\
\hline & Point $1-11.92 \times 6.27$ & & & Point $1-12.06 \times 6.09$ & \\
\hline \multirow[t]{3}{*}{4.5} & Point $2-11.96 \times 6.15$ & 20.92 & 5.5 & Point $2-12.06 \times 5.93$ & 31.73 \\
\hline & & & & Point $3-12.06 \times 5.87$ & \\
\hline & Point $1-12.16 \times 5.83$ & & & Point $1-11.97 \times 5.97$ & \\
\hline \multirow[t]{2}{*}{4.6} & Point $2-12.04 \times 5.73$ & 25.51 & 5.6 & Point $2-11.92 \times 5.92$ & 26.95 \\
\hline & & & & Point $3-12.17 \times 5.92$ & \\
\hline
\end{tabular}


Table 2. Modulus of Elasticity, $\mathrm{E}_{\mathrm{M}, 12 \%}(\mathrm{MPa})$

\begin{tabular}{|c|c|c|c|c|c|c|c|}
\hline Beam & Point & Position A & Position B & Beam & Point & Position A & Position B \\
\hline 4.1 & 1 & 12243 & 12506 & 5.1 & 1 & 16222 & 15865 \\
\hline 4.2 & 1 & 18607 & 17328 & 5.2 & 1 & 12937 & 12970 \\
\hline 4.3 & 1 & 16419 & 16447 & 5.3 & 1 & 15961 & 16146 \\
\hline 4.4 & 1 & 18346 & 17802 & 5.4 & 1 & 14605 & 14275 \\
\hline 4.5 & 1 & 18590 & 18986 & 5.5 & 1 & 15307 & 16222 \\
\hline 4.6 & 1 & 15800 & 13938 & 5.6 & 1 & 16956 & 16882 \\
\hline 4.1 & 2 & 11588 & 11643 & 5.1 & 2 & 16626 & 16437 \\
\hline 4.2 & 2 & 19265 & 17952 & 5.2 & 2 & 14154 & 13244 \\
\hline 4.3 & 2 & 16383 & 16468 & 5.3 & 2 & 16989 & 17375 \\
\hline 4.4 & 2 & 17210 & 17132 & 5.4 & 2 & 14948 & 14405 \\
\hline 4.5 & 2 & 18255 & 18163 & 5.5 & 2 & 16886 & 17006 \\
\hline \multirow[t]{5}{*}{4.6} & 2 & 17041 & 15526 & 5.6 & 2 & 17860 & 17336 \\
\hline & & & & 5.1 & 3 & 17364 & 17529 \\
\hline & & & & 5.2 & 3 & 14907 & 14103 \\
\hline & & & & 5.3 & 3 & 17810 & 17874 \\
\hline & & Position A & Position B & 5.4 & 3 & 14530 & 14190 \\
\hline \multicolumn{2}{|c|}{ Total Average } & 16288 & 15982 & 5.5 & 3 & 17884 & 17597 \\
\hline \multicolumn{2}{|c|}{ Variance } & 3606847 & 3555183 & 5.6 & 3 & 16944 & 16112 \\
\hline
\end{tabular}

Table 3. $\mathrm{E}_{\mathrm{M}, 12 \%}(\mathrm{MPa})$ values at points 1 and 2 for the $4 \mathrm{~m}$ long beams

\begin{tabular}{|c|c|c|c|c|c|c|}
\hline \multirow[b]{2}{*}{ Beam } & \multicolumn{3}{|c|}{ Position A } & \multicolumn{3}{|c|}{ Position B } \\
\hline & Point 1 & Point 2 & Difference \% & Point 1 & Point 2 & Difference \% \\
\hline 4.1 & 12243 & 11588 & 5.66 & 12506 & 11643 & 7.42 \\
\hline 4.2 & 18607 & 19265 & 3.54 & 17328 & 17952 & 3.60 \\
\hline 4.3 & 16419 & 16383 & 0.22 & 16447 & 16468 & 0.13 \\
\hline 4.4 & 18346 & 17210 & 6.60 & 17802 & 17132 & 3.91 \\
\hline 4.5 & 18590 & 18255 & 1.83 & 18986 & 18163 & 4.53 \\
\hline 4.6 & 15800 & 17041 & 7.86 & 13938 & 15526 & 11.39 \\
\hline Average & 16668 & 16624 & & 16168 & 16147 & \\
\hline Variance & 6133305 & 7114828 & & 6083106 & 5813233 & \\
\hline \multicolumn{3}{|c|}{ Average of the difference (\%) } & 4.28 & & & 5.16 \\
\hline
\end{tabular}

Table 4. $\mathrm{E}_{\mathrm{M}, 12 \%}(\mathrm{MPa})$ values at points 1 and 2 for the $5 \mathrm{~m}$ long beams

\begin{tabular}{|c|c|c|c|c|c|c|}
\hline \multirow[b]{2}{*}{ Beam } & \multicolumn{3}{|c|}{ Position A } & \multicolumn{3}{|c|}{ Position B } \\
\hline & Ponto 1 & Ponto 2 & Difference \% & Ponto 1 & Ponto 2 & Difference \% \\
\hline 5.1 & 16222 & 16626 & 2.49 & 15865 & 16437 & 3.61 \\
\hline 5.2 & 12937 & 14154 & 9.41 & 12970 & 13244 & 2.12 \\
\hline 5.3 & 15961 & 16989 & 6.44 & 16146 & 17375 & 7.61 \\
\hline 5.4 & 14605 & 14948 & 2.35 & 14275 & 14405 & 0.91 \\
\hline 5.5 & 15307 & 16886 & 10.31 & 16222 & 17006 & 4.83 \\
\hline 5.6 & 16956 & 17860 & 5.33 & 16882 & 17336 & 2.69 \\
\hline Average & 15381 & 16244 & & 15393 & 15967 & \\
\hline Variance & 2030196 & 1954901 & & 2163603 & 3002633 & \\
\hline \multicolumn{3}{|c|}{ Average of the difference (\%) } & 6.06 & & & 6.63 \\
\hline
\end{tabular}


Table 5. $\mathrm{E}_{\mathrm{M}, 12 \%}(\mathrm{MPa})$ values at points 1 and 3 for the $5 \mathrm{~m}$ long beams

\begin{tabular}{|c|c|c|c|c|c|c|}
\hline \multirow[b]{2}{*}{ Beam } & \multicolumn{3}{|c|}{ Position A } & \multicolumn{3}{|c|}{ Position B } \\
\hline & Point 1 & Point 3 & Difference \% & Point 1 & Point 3 & Difference \% \\
\hline 5.1 & 16222 & 17364 & 7.04 & 15865 & 17529 & 10.48 \\
\hline 5.2 & 12937 & 14907 & 15.23 & 12970 & 14103 & 8.74 \\
\hline 5.3 & 15961 & 17810 & 11.59 & 16146 & 17874 & 10.70 \\
\hline 5.4 & 14605 & 14530 & 0.51 & 14275 & 14190 & 0.60 \\
\hline 5.5 & 15307 & 17884 & 16.83 & 16222 & 17597 & 8.48 \\
\hline 5.6 & 16956 & 16944 & 0.07 & 16882 & 16112 & 4.78 \\
\hline Average & 15331 & 16573 & & 15393 & 16234 & \\
\hline Variance & 2018102 & 2192258,46 & & 2163603 & 2990878 & \\
\hline \multicolumn{3}{|c|}{ Average of the differences (\%) } & 8.54 & & & 7.30 \\
\hline
\end{tabular}

Table 6. $\mathrm{E}_{\mathrm{M}, 12 \%}(\mathrm{MPa})$ values at points 2 and 3 for the $5 \mathrm{~m}$ long beams

\begin{tabular}{|c|c|c|c|c|c|c|}
\hline \multirow[b]{2}{*}{ Beam } & \multicolumn{3}{|c|}{ Position A } & \multicolumn{3}{|c|}{ Position B } \\
\hline & Point 2 & Point 3 & Difference \% & Point 2 & Point 3 & Difference \% \\
\hline 5.1 & 16626 & 17364 & 4.44 & 16437 & 17529 & 6.64 \\
\hline 5.2 & 14154 & 14907 & 5.32 & 13244 & 14103 & 6.49 \\
\hline 5.3 & 16989 & 17810 & 4.83 & 17375 & 17874 & 2.87 \\
\hline 5.4 & 14948 & 14530 & 2.87 & 14405 & 14190 & 1.51 \\
\hline 5.5 & 16886 & 17884 & 5.91 & 17006 & 17597 & 3.48 \\
\hline 5.6 & 17860 & 16944 & 5.41 & 17336 & 16112 & 7.60 \\
\hline Average & 16244 & 16573 & & 15967 & 16234 & \\
\hline Variance & 1954901 & 2192258 & & 3002633 & 2990878 & \\
\hline \multicolumn{3}{|c|}{ Average of the differences (\%) } & 4.80 & & & 4.76 \\
\hline
\end{tabular}

Table 7. Moment of inertia values (I)

\begin{tabular}{|c|c|c|c|c|c|}
\hline \multicolumn{6}{|c|}{ Position A } \\
\hline Beam & Point & I $\left(\mathrm{cm}^{4}\right)$ & Beam & Point & I $\left(\mathrm{cm}^{4}\right)$ \\
\hline \multirow{3}{*}{4.1} & 1 & 234.18 & \multirow{3}{*}{5.1} & 1 & 197.47 \\
\hline & \multirow[t]{2}{*}{2} & \multirow[t]{2}{*}{249.57} & & 2 & 204.62 \\
\hline & & & & 3 & 197.83 \\
\hline \multirow{3}{*}{4.2} & 1 & 229.96 & \multirow{3}{*}{5.2} & 1 & 222.55 \\
\hline & \multirow[t]{2}{*}{2} & \multirow[t]{2}{*}{218.17} & & 2 & 222.00 \\
\hline & & & & 3 & 224.17 \\
\hline \multirow{3}{*}{4.3} & 1 & 231.86 & \multirow{3}{*}{5.3} & 1 & 254.69 \\
\hline & \multirow[t]{2}{*}{2} & \multirow[t]{2}{*}{215.28} & & 2 & 247.31 \\
\hline & & & & 3 & 239.35 \\
\hline \multirow{3}{*}{4.4} & 1 & 245.52 & \multirow{3}{*}{5.4} & 1 & 222.74 \\
\hline & \multirow[t]{2}{*}{2} & \multirow[t]{2}{*}{232.62} & & 2 & 228.31 \\
\hline & & & & 3 & 237.80 \\
\hline \multirow{3}{*}{4.5} & 1 & 244.84 & \multirow{3}{*}{5.5} & 1 & 227.00 \\
\hline & \multirow[t]{2}{*}{2} & \multirow[t]{2}{*}{231.64} & & 2 & 209.57 \\
\hline & & & & 3 & 203.27 \\
\hline \multirow{3}{*}{4.6} & 1 & 200.80 & \multirow{3}{*}{5.6} & 1 & 212.24 \\
\hline & \multirow[t]{2}{*}{2} & \multirow[t]{2}{*}{188.76} & & 2 & 206.09 \\
\hline & & & & 3 & 210.41 \\
\hline
\end{tabular}

Comparison between the $E_{M, 12 \%}$, in positions $A$ and $B$ :

The assays allow to compare results with $\mathrm{L} / \mathrm{h}=50$ and $\mathrm{L} / \mathrm{h}$ $=25$ respectively in positions $\mathrm{A}$ and $\mathrm{B}$. For the hypothesis $\mathrm{H}_{0}$ according to which the averages are statistically equivalents, according to Table 2, one has:

$\mathrm{S}=2072.97$ and $\mathrm{t}=0.572$; For $\mathrm{U}=58, \mathrm{t}_{0.025}=-2.00$ and $\mathrm{t}_{0.975}=2.00$

Thus: $-2.00<\mathrm{t}<2.00$.

At the $95 \%$ confidence level one can accept the hypothesis $\mathrm{H}_{0}: \mu_{\mathrm{A}}=\mu_{B}$.

Comparison between the $E_{M, 12 \%}$, in points 1 and 2 for the $4.00 \mathrm{~m}$ long beam:

For the hypothesis $\mathrm{H}_{0}$ that the averages $\mu_{1}=\mu_{2}$ are statistically equivalent, respectively in the points 1 and 2 for the $4.00 \mathrm{~m}$ long beam, according to Table 3 , one have:

\section{a) Position $A$}

$\mathrm{S}=2819.37$ and $\mathrm{t}=0.0269$; for $\mathrm{U}=10, \mathrm{t}_{0.025}=-2.23$ and $\mathrm{t}_{0.975}=2.23$;

Thus: $-2.23<\mathrm{t}<2.23$.

At the 95\% confidence level one can accept the hypothesis $\mathrm{H}_{0}: \mu_{1}=\mu_{2}$.

\section{b) Position B}

$\mathrm{S}=2671.67$ and $\mathrm{t}=0.0130$; for $\mathrm{U}=10, \mathrm{t}_{0.025}=-2.23$ and $\mathrm{t}_{0.975}=2.23$; 
Thus: $-2.23<\mathrm{t}<2.23$.

At the 95\% confidence level one can accept the hypothesis $\mathrm{H}_{0}: \mu_{1}=\mu_{2}$

Comparison between the $E_{M, 12 \%}$, in points 1 and 2 for the $5.00 \mathrm{~m}$ long beam:

For the hypothesis $\mathrm{H}_{0}$ that the averages $\mu_{1}=\mu_{2}$ are statistically equivalent, respectively in the points 1 and 2 for the $5.00 \mathrm{~m}$ long beam, according to Table 4, one have:

\section{a) Position $\mathrm{A}$}

$\mathrm{S}=1546.30$ and $\mathrm{t}=-0.967 ;$ for $\mathrm{U}=10, \mathrm{t}_{0.025}=-2.23$ and $\mathrm{t}_{0.975}=2.23$;

Thus: $-2.23<\mathrm{t}<2.23$.

At the 95\% confidence level one can accept the hypothesis $\mathrm{H}_{0}: \mu_{1}=\mu_{2}$.

\section{b) Position B}

$\mathrm{S}=1760.61$ and $\mathrm{t}=-0.565 ;$ for $\mathrm{U}=10, \mathrm{t}_{0.025}=-2.23$ and $\mathrm{t}_{0.975}=2.23$;

Thus: $-2.23<\mathrm{t}<2.23$.

At the $95 \%$ confidence level one can accept the hypothesis $\mathrm{H}_{0}: \mu_{1}=\mu_{2}$.

\section{Comparison between the $\mathrm{E}_{\mathrm{M}, 12 \%}$, in points 1 and 3 for the} $\mathbf{5 . 0 0} \mathrm{m}$ long beam:

For the hypothesis $\mathrm{H}_{0}$ that the averages $\mu_{1}=\mu_{3}$ are statistically equivalent, respectively in the points 1 and 3 for the $5.00 \mathrm{~m}$ long beam, according to Table 5, one have:

\section{a) Position $\mathrm{A}$}

$\mathrm{S}=1589.41$ and $\mathrm{t}=-1.353 ;$ for $\mathrm{U}=10, \mathrm{t}_{0.025}=-2.23$ and $\mathrm{t}_{0.975}=2.23$;

Thus: $-2.23<\mathrm{t}<2.23$.

At the 95\% confidence level one can accept the hypothesis $\mathrm{H}_{0}: \mu_{1}=\mu_{3}$

\section{b) Position B}

$\mathrm{S}=1758.60$ and $\mathrm{t}=-0.828$; for $\mathrm{U}=10, \mathrm{t}_{0.025}=-2.23$ and $\mathrm{t}_{0.975}=2.23$;

Thus: $-2.23<\mathrm{t}<2.23$.

At the 95\% confidence level one can accept the hypothesis $\mathrm{H}_{0}: \mu_{1}=\mu_{3}$.

\section{Comparison between the $\mathrm{E}_{\mathrm{M}, 12 \%}$, in points 2 and 3 for the} $5.00 \mathrm{~m}$ long beam:

For the hypothesis $\mathrm{H}_{0}$ that the averages $\mu_{2}=\mu_{3}$ are statistically equivalent, respectively in the points 2 and 3 for the $5.00 \mathrm{~m}$ long beam, according to Table 6, one have:

\section{a) Position $\mathrm{A}$}

$\mathrm{S}=1577.43$ and $\mathrm{t}=-0.361 ;$ for $\mathrm{U}=10, \mathrm{t}_{0.025}=-2.23$ and $\mathrm{t}_{0.975}=2.23$;

Thus: $-2.23<\mathrm{t}<2.23$.

At the 95\% confidence level one can accept the hypothesis $\mathrm{H}_{0}: \mu_{2}=\mu_{3}$

\section{b) Position B}

$\mathrm{S}=1896.34$ and $\mathrm{t}=-0,243$; for $\mathrm{U}=10, \mathrm{t}_{0.025}=-2.23$ and $\mathrm{t}_{0.975}=2.23$;
Thus: $-2.23<\mathrm{t}<2.23$.

Ao nível de significância de 95\%, pode-se aceitar a hipótese $\mathrm{H}_{0}: \mu_{2}=\mu_{3}$.

At the 95\% confidence level one can accept the hypothesis $\mathrm{H}_{0}: \mu_{1}=\mu_{2}$.

\section{Analysis of the Moment of inertia variations:}

In position $\mathrm{A}$ the nominal moment of inertia is $\mathrm{I}_{\text {Nominal }}=$ $216.00 \mathrm{~cm}^{4}$. With the changes in dimensions as a function of the processing, the moments of inertia present the following behavior in the points in which they were determined:

Average value: $\mathrm{I}_{\text {Average }}=223.02 \mathrm{~cm}^{4}$;

Standard deviation: $\mathrm{s}=17.36 \mathrm{~cm}^{4}$; and

Variance coefficient: $\mathrm{cv}=7.78 \%$.

Thus one have the ratio: $\mathrm{I}_{\text {Nominal }}=0.97 \mathrm{I}_{\text {Average }}$.

\section{Conclusions}

For the beam without visually detectable defects, it is possible to determine the bending modulus of elasticity only for position $\mathrm{A}$, once the results in position $\mathrm{A}$ and $\mathrm{B}$ were statistically equivalents within the $95 \%$ confidence level. In the specimens investigated it was demonstrated that for two points distant one or two meters the $E_{M}$ values were also statistically equivalents at the 95\% confidence level, in a such way that the four or five meter long beam could have their $E_{M}$ values determined in a single assay. The structural pieces are usually marketed with two up to six meter long with their lengths varying from half to half meter. For such pieces the $\mathrm{L} / \mathrm{h}$ ratio is significant and allow a single assay for the most of the dimensions available in the market.

In the measurements performed in the cross sections of the beam investigated, a 3\% change in the dimensions was observed which was attributed to the processing. As a consequence the change in the moment of inertia varies $12 \%$. In practice a 0.97 ratio between the nominal moment of inertia and the average value for this figure. It is a preliminary estimative to be confirmed by the evaluation of a higher sampling of structural pieces. The resulting value will used as a suggestion for changing in the Brazilian standard [13] in which it will be suggested the non-destructive procedures for classifying timber structural pieces.

Using simpler equipment as dynamometer ring with precision of $1.0 \mathrm{~N}$, mechanical extensometer, a caliper with precision of $0.01 \mathrm{~mm}$ and an electrical meter of humidity, it is possible to determine the $\mathrm{E}_{\mathrm{M}}$ of structural timber pieces with enough precision. As demonstrated by [8] only one level of loading is enough, under elastic regime, to define the $\mathrm{P} \backslash \mathrm{f}$ ratio. According to [11] the deformation speeds under usual conditions from 6.3 up to $37.0 \mathrm{MPa} / \mathrm{min}$ do not affect the $\mathrm{E}_{\mathrm{M}}$ values and displacements at the loading point in the order of $\mathrm{L} / 200(\mathrm{~cm})$ provoke deformation in the elastic regime for most of the natural specimens.

The impact of the classifying cost in the final price of the timber will not bad consequences once the costumer will save buying lower volume of timber and using higher 
resistance classes with the possibility of acquiring pieces of the first level allowing that the partial modification coefficient $\mathrm{K}_{\bmod 3}$ be equal to 1.0 , according to the Brazilian standard [13], representing a raise of $25 \%$ in the resistance of calculus regarding the non-classified pieces.

Finally, it is recommended that the present work go ahead expanding the experimental range in order to reach other species (including those from reforest) other commercial dimensions $(6.0 \times 16.0 ; 5.0 \times 6.0 ; 2.5 \times 30.0 \mathrm{~cm}$, as examples) and other timber suppliers. It is also recommended confirming the results from [9] for six species by appropriate statistical evaluation of the data already available for fifty species, looking for a relationship between the static bending modulus of elasticity and the resistance of the wood to the compression parallel to the fibers.

\section{REFERENCES}

[1] Lahr, F. A. R.; Christoforo, A. L.; Silva, C. E. G.; Andrade Junior, J. R.; Pinheiro, R. V. Avaliação de propriedades físicas e mecânicas de madeiras de Jatobá (Hymenaea stilbocarpa) com diferentes teores de umidade e extraídas de regiões distintas. Revista Árvore (Impresso), v. 40, p. 147-154, 2016.

[2] Christoforo, A. L.; Panzera, T. H.; Silva, L. J.; Araujo, V. A. ; Silva, D. A. L. ; Rocco, F. A. L. Evaluation of the Modulus of Elasticity in Damaged Wooden Beams. International Journal of Materials Engineering, v. 5, p. 92-97, 2015.

[3] Christoforo, A. L.; Almeida, T. H.; Almeida, D. H.; Santos, J. C.; Panzera, T. H.; Lahr, F. A. R. Shrinkage for some wood species estimated by density. International Journal of Materials Engineering, v. 6, p. 23-27, 2016.

[4] Almeida, D. H.; Cavalheiro, R. S.; Macedo, L. B.; Calil Neto, C.; Christoforo, A. L.; Calil Junior, C.; Rocco, F. A. L. Evaluation of Quality in the Adhesion of Glued Laminated Timber (Glulam) of Paricá and Lyptus Wood Species. International Journal of Materials Engineering, v. 4, p. 114-118, 2014.
[5] Icimoto, F. H.; Calil Neto, C.; Ferro, F. S.; Macedo, L. B.; Christoforo, A. L.; Lahr, F. A. R.; Calil Junior, C. Influence of lamellar thickness on strength and stiffness of glued laminated timber beams of Pinus oocarpa. International Journal of Materials Engineering, v. 6, p. 51-55, 2016.

[6] Cavalheiro, R. S.; Calil Neto, C.; Christoforo, A. L.; Calil Junior, C.; Lahr, F. A. R. Evaluation of shear strength and delamination of Paricá (Schizolobium amazonicum) glued laminated timber. International Journal of Materials Engineering, v. 6, p. 60-65, 2016.

[7] Bittencourt, R. M. Madeira Comercializada $\times$ Madeira Especificada para Construção. In: Encontro Brasileiro em Madeiras e em Estruturas de Madeiras, 5. Anais, Belo Horizonte, (MG), Ebramem, v. 2, 1995.

[8] Furiati, M. Classificação Estrutural de Peças de Madeira. Dissertação de mestrado, Escola de Engenharia de São Carlos, Universidade de São Paulo, São Carlos - SP, p. 32 - 49, 1981.

[9] Lahr, F. A. R. Sobre a Determinação de Propriedades Elásticas da Madeira. Tese de doutorado, Escola de Engenharia de São Carlos, Universidade de São Paulo, São Carlos - SP, 1983.

[10] Melo, J. E. Classificação Mecânica de Peças Estruturais de Madeira. Dissertação de mestrado, Engenharia de São Carlos, Universidade de São Paulo, São Carlos - SP, 84 p., 1984.

[11] Otto, R. I. C. Velocidade de Ensaios na Flexão de Peças de Madeira. Dissertação de mestrado, Engenharia de São Carlos, Universidade de São Paulo, São Carlos - SP, 114 p, 1985.

[12] Okimoto, F., Pfister, G. E Calil Jr, C. Classificação Visual e Mecânica de Madeiras Estruturais. In: Encontro Brasileiro em Madeiras e em Estruturas de Madeiras, 5. Anais, Belo Horizonte, (MG), Ebramem, 1995.

[13] Associação Brasileira de Normas Técnicas. NBR 7190. Projeto de Estruturas de Madeira. Rio de Janeiro. Item 6.2.1, item 6.4.4, 1997.

[14] Spiegel, M. R. Estatística. 3. ed., São Paulo, Makron Books, Coleção Shaum, p. 286, 1983. 